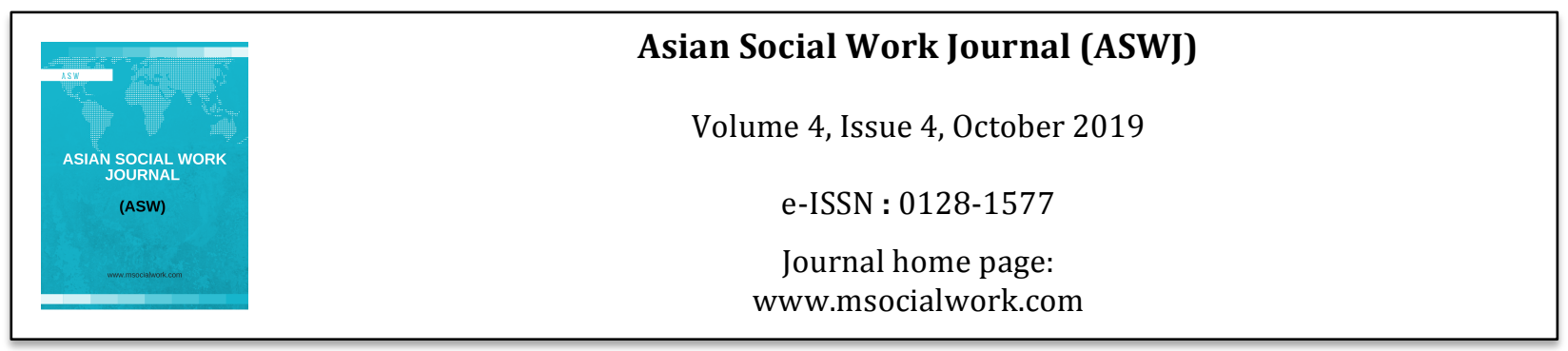

\title{
Identifying Parties of Support System to Prevent Suicide Behavior of Adolescents
}

\author{
Kanya Eka Santi ${ }^{1}$, Alfrojems $^{2}$, Chairani ${ }^{1}$ \\ ${ }^{1}$ Directorate of Social Rehabilitation for Children, Directorate General of Social Rehabilitation, Ministry of Social Affairs \\ of The Republic of Indonesia \\ 2Department of Social Welfare, Faculty of Social and Political Sciences, Universitas Indonesia \\ Corrrespondence: Alfrojems (alfro.jems@gmail.com)
}

\begin{abstract}
Suicide cases are a worldwide phenomenon, especially if the perpetrators of suicide are Adolescents, so it is not surprising that 7 (seven) suicides committed by adolescents in Dompu Regency, West Nusa Tenggara Province, Indonesia are an interesting case to explore and traced. This article aims to explore information about suicidal behavior in adolescents, especially in the area of Dompu Regency, West Nusa Tenggara Province. The research method in this article is qualitative with descriptive type. The results of this study indicate that there are a number of conditions that cause adolescents in Dompu regency to become vulnerable in committing suicide, this is also followed by quite strong reasons. In addition, this study also succeeded in exploring several parties who were able to play a role in preventing suicide behavior in adolescents. The recommendations presented in this article are the need to strengthen support through educational institutions that involve peers to provide support to other adolescents so as to be able to find solutions to any problems experienced and be able to prevent suicidal behavior in adolescents.
\end{abstract}

Key words: suicide, adolescents, peer support

\section{Introduction}

Suicide is a phenomenon that is a problem of the world. Based on data obtained from WHO in 2018 throughout the world, it is recorded that there are nearly 800 thousand suicides that occur worldwide. Indonesia itself is based on data obtained from WHO reports which show that Indonesia has a suicide rate ratio of 3.7 per 100,000 people which finally ranks Indonesia with 159 countries with the highest suicide rate in the world. When viewed this condition shows that the suicide rate in Indonesia is not too alarming when compared to other accounts such as Guyana (30.2), South Korea (20.2), Japan (14.3), and even the United States (13.7). Globally, the figure of 800 thousand may not be too scary for some groups of people, but if the WHO report is narrowed and focused on vulnerable people aged 10 to 24, the shocking fact is that death caused by suicide is the second largest killer.

Based on the results of research conducted by Janice Ka Yan Cheng, Tonya L Fancher, Milin Ratanasen, et al. The title "lifetime suicidal ideation and suicide attempts in Asian Americans" suggests that the role of culturally related variables (family conflicts, perceived discrimination, and ethnic identity) on suicidal ideation and suicide attempts in a nationally representative sample of 2,095 Asian Americans. Important covariates were sociodemographic characteristics (gender, age, marital status, years of education, household poverty, and nativity status), depressive and anxiety disorders, and number of chronic conditions. Gender related correlates were also explored. The lifetime prevalence of 
suicidal ideation and attempts was $8.8 \%$ and $2.5 \%$, respectively. Female gender, family conflict, perceived discrimination, and the presence of lifetime depressive or anxiety disorders were positively correlated with suicidal ideas and attempts. A high level of identification with one's ethnic group was associated with lower rates of suicide attempts. Among Asian men, but not women, the presence of chronic medical conditions was associated with suicidal ideation. Findings highlight the contributions to suicide risk of cultural factors and gender differences in Asian Americans.

Indonesia is a country that has quite diverse natural and cultural wealth and this is also supported by religious life that is quite strongly embraced by the people of Indonesia. this also applies to the area of Dompu Regency, West Nusa Tenggara Province. Therefore the suicide case that occurred managed in the region to attract national attention, especially the perpetrators of suicide are all Adolescents who are still sitting in school. So it gives a desire by researchers to conduct deeper searches, to find out the reasons for adolescents to commit suicide and which parties actually have an important role in efforts to prevent suicide behavior.

Adolescents are one of the stages of human development with a fairly high personal conflict. According to Hurlock (1980) states that the beginning of adolescence lasts approximately thirteen to seventeen years, and the end of adolescence begins from the age of 16 to 17 years to 18 years. Therefore this adolescence can be said to be quite short. In addition, at this time there are also fairly rapid changes, such as physical, and this certainly needs to be accompanied by rapid rapid mental development, especially in the early teens. All of these changes require mental adjustment and the need to form new attitudes, values and interests. Based on these explanations, it is found that adolescents are a phase that is quite vulnerable to suicidal behavior.

An effort to prevent adolescents from committing suicide, social support is needed for these adolescents to avoid suicidal behavior. According to King: 2012 social support is information or feedback from others that shows that someone is loved and cared for, valued, and respected, and involved in a network of communication and mutual obligations. In addition, this support can be sourced from several parties as stated by Wangmuba: 2009 which states that there are actually three sources of social support namely family, peers, and the community. peers have a significant role because according to Santrok: 2003 peers play a role to provide physical support, ego support, social comparison, and attention, so that the strengthening of peer support is important in efforts to prevent suicide behavior towards adolescents.

\section{Methodology}

This study uses a qualitative approach with a descriptive type. The reason for using this type of approach is because it is in line with the purpose of this study which is to explore information related to the causes of adolescents to commit suicide. This is in line with the understanding of qualitative research as presented by Neuman (2014) "Qualitative methods, by contrast, are best understood as data enhancers. When data is enhanced, it is possible to see more aspects of cases more clearly." The data collection technique is done through group discussions with focus group discussion formats, observations, and documentation studies that are relevant to the issue of suicide.

\section{Population and Sample}

The population in this study is the party that is very closely related to the perpetrators of suicide namely the school and students from each school detected. So that the sampling technique used is nonprobability with the type of purposive sampling. The sampling technique using purposive or judgmental sampling non-probability sampling technique according to Neuman (2014) is a non-random sample in which researchers use various methods to find all possible specific cases and the population is difficult to reach. Based on this, students and teachers were selected from each school with representatives from each school consisting of eight students and two teachers so that the total informants were selected is 40 informants. 


\section{Findings}

This study the data found were then grouped into two namely the causes of suicide and those who have an important role in overcoming the problem of suicide behavior in adolescents. The explanation is as follows:

\section{Causes of Suicide}

Based on the results through the FGD (Focus Group Discussion) process, several facts were obtained that contributed to the occurrence of suicidal behavior for adolescents such as:

\section{Lack Of Parental Attention}

The people of Dompu Regency, West Nusa Tenggara Province, are one of the areas that have the intensity to look for work from outside the city, island or even abroad. This condition is often done by parents, with the hope that they as parents are able to meet the needs needed by their children. This condition certainly has consequences for children not to do intensive interaction with their parents, because even this condition most of the children live in the homes of other family members such as grandmothers and grandfathers, aunts and uncles or even choose to live alone by contracting a residence.

Such conditions they have to go through even for years. On the other hand, the communication infrastructure in the Dompu Regency area is said to be quite minimal so that to interact or communicate via the internet, the local community must work harder in terms of finding a signal, and even if to get a good signal, the community is demanded to pay more for the sake of obtaining a data package or credit to be able to communicate using internet network facilities. Even this condition ultimately has significant effects such as lack of communication, lack of a place to complain, lack of attachment to parents with Adolescents due to their parents working well outside the city, island or even abroad.

Separation of adolescents with their parents, whether it is father, mother or even both at the same time causes adolescents to finally feel unnoticed, causing them to feel the need to do something in order to get the attention of both parents, where one of them is committing suicide. So it is not surprising that the lack of parental attention points eventually become one of the causes of suicide in adolescents.

\section{Violence}

Violence experienced by adolescents has a variety of variations, but based on the results of data collection most of the informants mentioned that verbal violence is a type of violence that they often get. Verbal violence can include insults about the physical condition or family condition of these children and this type of violence often occurs in women. In addition there are also other types of violence that occur in the form of physical violence in the form of beatings or coercion of fights, where this is more common in boys adolescent.

Violence that occurs in adolescents is mostly caused by adolescents not really understanding the concept or concept of violence, punishment from perpetrators of violence, or even the impact of violence itself. Adolescents have the argument that it is just exclamation and does not have a specific purpose. Even if they have to contend with the physical according to them it is a form of consequences for the behavior that has been previously shown by the party receiving the treatment, or in other words the beatings committed are a form of their reaction to excessive acts committed by the victim receiving the physical abuse treatment.

\section{Parties to Participate in Preventing Suicide Behaviors}

Based on the FGD activities carried out for approximately two days, it was found several parties who, according to the informants, were actually able to have a greater role in trying to prevent suicidal 
behavior in adolescents, including family and parents, peers and teachers or the school. The family and parents are chosen because they are considered as the party that has the most core close relationship with the group of adolescents, besides that the parents and family are considered as the party who can best understand the character of the teenager, who is expected to be able to build trust in the adolescent so as to prevent behavior suicide in Adolescents. Peers are the second group considered as those who are able to strive to prevent suicidal behavior, this is because peers are those who have a lot of communication intensity with adolescents, besides that peers often become a place for these adolescents to give complaints.

In addition, other parties that are considered to have a significant role in preventing suicidal behavior towards adolescents are the school, in this case the teacher. The reason schools or teachers become parties that play an important role in preventing suicidal behavior in adolescents is because most of the time spent by Adolescents is at school so that the interaction between adolescents as students and teachers has quite a lot of intensity. The intensity caused a strong relationship between teachers and adolescents, which of course finally gave a sense of comfort for adolescents in expressing the problem. Therefore the school in this case the teacher has a hand in overcoming suicide behavior in adolescents.

\section{Discussion}

Suicidal behavior in adolescents that occur in 7 (seven) adolescents in Dompu Regency, West Nusa Tenggara Province, provides a clear picture of the importance of the presence of parents in the process of stages of adolescent development. This can be seen from the findings of this study through the focus group discussion. In this activity it was found that the cause of adolescents committing suicide was due to the lack of parental attention to them due to circumstances where their parents had to leave them to look for sources of income or employment in order to meet the needs of children in this case the adolescents themselves. This condition is certainly inevitable because of the limited opportunities in accessing employment in the region especially with decent wages or salaries. While their needs especially for children or adolescents continue to develop rapidly. This condition is getting stronger especially with the results related to parties who play an important role in trying to prevent adolescent suicidal behavior, where parents or family have a significant role. Contradictions between the role and presence of parents in efforts to prevent adolescent suicide behavior provides a reason for the need for an alternative other party that can be maximized as an effort to prevent suicide behavior in adolescents. On the other hand there are also factors of violence that cause teenage suicidal behavior. Violence itself is carried out largely by the closest circle of adolescents themselves, which is more due to the lack of sufficient information to them about the concept, as well as the impact caused by physical and nonphysical violence.

The results of this study through the focus group discussion activities there are two other parties that are considered to have a significant role in trying to prevent the behavior of adolescent peers and schools as an alternative party that can be maximized to prevent suicide behavior in adolescents, especially in Dompu Regency, West Nusa Tenggara Province. The choice of peers and school or teachers in preventing suicidal behavior in Adolescents is certainly not an excuse. Associated with efforts to prevent suicidal behavior in adolescents, what is needed is about how the environment provides support to adolescents. Then related to this matter will relate to the concept of social support where in social support according to Wangmuba: 2009 there are three parties who are sources of social support namely family, and the other two are peers and the community. through this statement of course peers are clearly mentioned while the school is a representation of the community itself.

\section{Conclusion}

Suicide behavior that occurred in Dompu Regency, West Nusa Tenggara Province is an event that reflects the importance of the presence of various parties such as families in the process of adolescent development. This is important because the lives of adolescents are quite short but are filled with the dynamics of change that are rapid enough to cause many problems that occur in adolescents, not to 
mention if the problem arises from their environment such as physical or non-physical actions. These conditions require problem solving and parents certainly have an important role especially in accompanying teens to go through the process. Conditions where the separation of parents and adolescents for economic reasons is certainly a fairly dilemmatic condition between the needs and the complete role of parents towards adolescents so as to cause adolescents to be less attentive from parents so that in dealing with other problems such as violence by their environment these adolescents will be very vulnerable.

Therefore the need for alternative other parties who are able to become a substitute for the role of the parent. In this study there are two parties who appear as holders of an important role in trying to prevent adolescent suicidal behavior namely peers and school or teachers. Both were chosen on the basis of trust because of the quite good communication intensity. So that the need for strengthening support through educational institutions that involve peers to provide support to other adolescents so as to be able to find solutions to any problems experienced and be able to prevent suicidal behavior in adolescents.

\section{References}

Janice Ka Yan Cheng, Tonya L Fancher, Milin Ratanasen, etc. (2010). Lifetime Suicidal Ideation And Suicide Attempts In Asian Americans. Asian Am J Psychol. 2010 Mar; 1(1): 18-30.

Neuman, W. Laurence. (2014). Social Research Methods: Qualitative and Quantitative Approaches. New York: Pearson

Hurlock, Elizabeth B. (1980). Psikologi Perkembangan: Suatu Pendekatan Sepanjang Rentang Kehidupan. Jakarta : Gramedia.

King, L. A. (2012). Psikologi Umum: Sebuah Pandangan Apresiatif $2^{\text {nd }}$ Book. Jakarta: Salemba Humanika.

Santrock (2003) John W. Adolescence. Perkembangan Remaja. $6^{\text {th }}$ Edition. Jakarta: Erlangga.

Santrock, John W. (2003). Life Span Development $2^{\text {nd }}$ Volume $5^{\text {th }}$ Edition. Jakarta :Erlangga.

The Jason Foundation. 2017. Youth Suicide Statistics 2017 CDC WISQARS. Amerika Serikat: The Jason Foundation. 2017. http://prp.jasonfoundation.com/facts/youth-suicide-statistics/ - Diaksis pada Agustus 2019.

Wangmuba, J.K (2009). Sumber Dukungan Sosial. Bandung: Alfabeta

World Health Organization. 2018. Suicide Data 2017. Amerika Serikat: World Health Organization. World Health Organization. https://www.who.int/mental_health/prevention/suicide/suicideprevent/en/ -Diakses pada Agustus 2019.

World Health Organization. 2018. Suicide Prevention. Amerika Serikat: World Health Organization. World Health Organization. https://www.who.int/health-topics/suicide\#tab=tab_1-Diakses pada Agustus 2019.

Zastrow, C. (2004). Introduction to social work and social welfare $\left(8^{\text {th }}\right.$ ed).Bellmont: Thomson. 